\title{
Connecting Learning with Students' Interests and Daily Lives with Project Assignment: "It is My Project."
}

\author{
Jung Oh \\ Kansas State University-Salina
}

\begin{abstract}
The General Chemistry course is a required or elective science course for engineering technology programs at Kansas State University at Salina. A hands-on 'Periodic Table' project in the General Chemistry course was assigned (1) to respect a variety of learning styles, (2) to foster connection between the basic science and engineering technology program courses, and (3) to connect student learning to personal interests and to have them enjoy an "ownership" of learning. The outcomes of this non-traditional teaching strategy were rewarding: (1) students were motivated in learning about the subjects, chemistry and various engineering technology areas, (2) students connected their personal areas of interests to academic majors programs and daily lives, and (3) many students in engineering technology programs incorporated kinesthetic learning styles for this assignment. In course portfolios and survey, students indicated that these assignments became enjoyable and valuable learning projects they were attached to in a personal way. This non-traditional teaching strategy has increased my enthusiasm to know my students on a personal level through observations of their unique talents and ways of connecting chemistry with engineering technology program courses.
\end{abstract}

\section{Introduction and objectives}

One of the seven principles of good practice in undergraduate education according to Chickiering and Gamon is to respect diverse talents and ways of learning. ${ }^{1}$ Among VARK (Visual, Aural, Read/Write, and Kinesthetic) learning styles by Bonwell and Fleming, ${ }^{2}$ kinesthetic style is observed as the predominant style among engineering technology students. ${ }^{3}$ Towns ${ }^{4}$ reports that applying Kolb's ELT (experiential learning theory) to the chemistry classroom provides a theoretical basis for expanding activities beyond traditional lectures. 
The General Chemistry course is a required or elective science course for engineering technology programs at Kansas State University at Salina and is considered as an Undergraduate General Education (UGE) course (http://www.k-state.edu/catl/uge/ ${ }^{5}$ ). UGE courses are to incorporate an active learning environment, an experiential context for whatever is studied, and to provide an opportunity for students to connect ideas.

The periodic table, one of most important chemistry references, is displayed in almost every chemistry classroom and laboratory and presented in most chemistry textbooks. The standard periodic table lists atomic symbols, atomic numbers and atomic masses for each element. With only symbols in the periodic table (e.g. potassium expressed as ${ }_{19} \mathrm{~K}^{39.10}$ ), students sometimes have difficulty connecting the symbol, $\mathrm{K}$, to the potassium metal.

A hands-on 'Periodic Table' project in General Chemistry course is assigned (1) to respect a variety of learning styles, (2) to foster connection between the basic science and engineering technology program courses students take, and (3) to connect student learning to personal interests and to have them enjoy an "ownership" of learning.

\section{Assignment and Students' Work Examples}

This project assignment is introduced with the following information:

To complete this project successfully, you will need to thoroughly research the element that you choose and utilize your personal creativity. Your first task is to design a concise yet informative presentation in $10 \mathrm{~cm}$ by $10 \mathrm{~cm}$ block of a designated element from the periodic table. You can design your block as "cool" as you want as long as it has the atomic number, the element symbol, and the mass number. Secondly, you are to convey the information about the element in a creative report, such as a short story, poem, song, poster, pamphlet, model, mobile, CD, video clip, etc. Keep in mind that the project is to connect us to and help us understand the world around us in every day life.

Each student chooses his or her element at least one week before the assignment due date. The student element presentations are assembled as a wall display periodic table in the Science Center at K-State at Salina. Each student is asked to do a better expression than the previously displayed element to avoid similarity and redundancy of well-known elements. The creative presentations are shared in the class, at public outreach activities, and through the online course web site (http://Online.ksu.edu) to exhibit student work and to encourage diverse expression. Examples of student's periodic table blocks are shown in Figure1 and examples of student's creative projects are shown in Figure 2 on the next page. Student's creative projects have included Power Point presentations, short stories, poems, rap songs, posters, pamphlets, models, mobiles, video clips, wind chime, quilt, computer programming, games, puppet shows, and others.

Proceedings of the 2005 American Society for Engineering Education Annual Conference \&Exposition Copyright (C) 2005, American Society for Engineering Education 

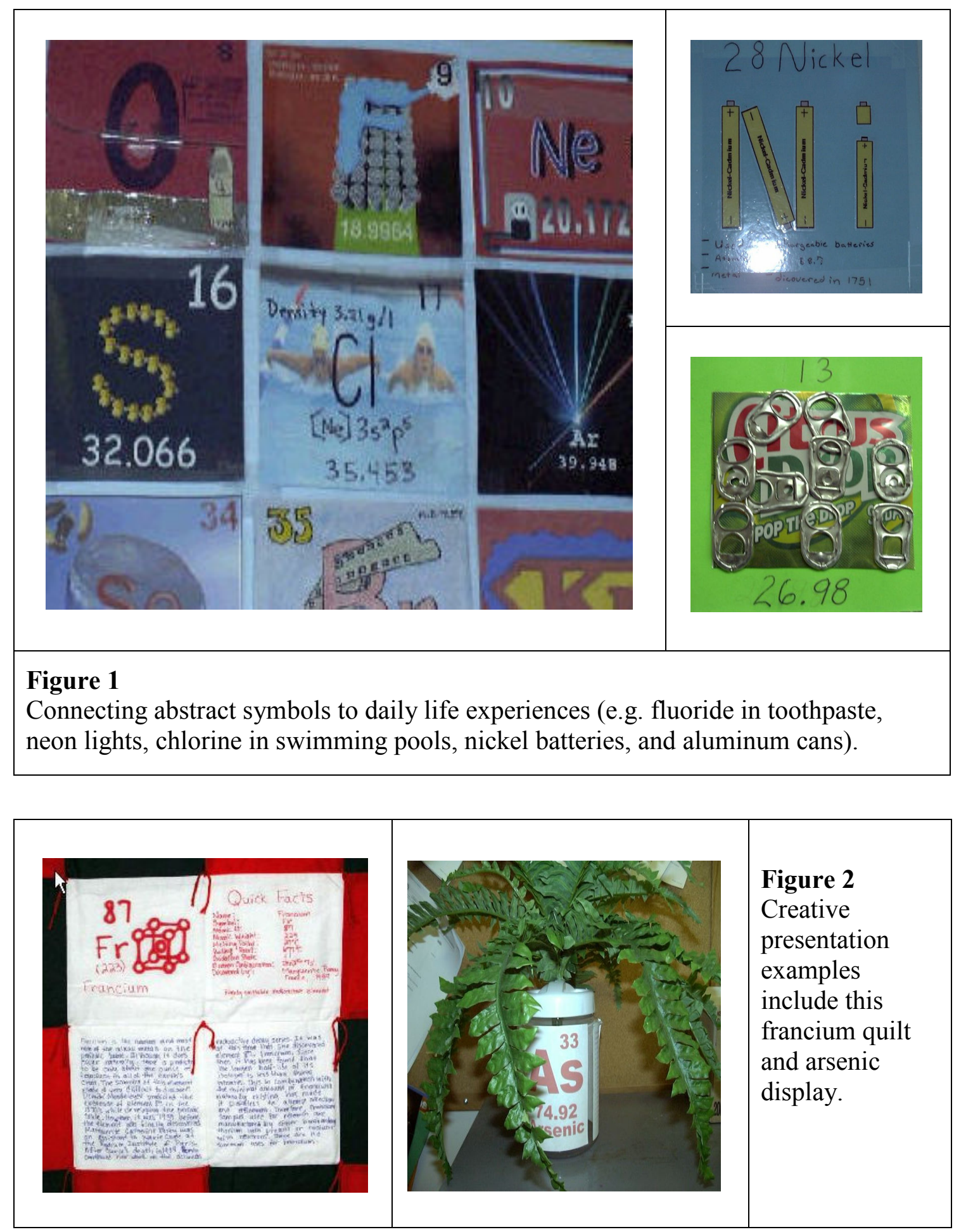

Many students in engineering technology programs have connected the project to their major programs. For example, one student in the electronic engineering technology program milled a square of single sided circuit board with the front side solid sheet of 
copper, without sealing it intentionally so that it could oxidize naturally. One student in mechanical engineering technology program worked on a milling project with an aluminum sheet with the CNC (Computer Numerical Control) mill code to express the symbol (Al), and the other student designed a metal welding display for symbol (Ar) indicating the use of argon gas in welding. Students in computer systems technology utilized Visual Basic and $\mathrm{C}++$ programming as tools to present information about their elements.

\section{Outcomes}

The outcomes from this non-traditional teaching strategy were very rewarding. The students were motivated and enjoyed gathering and presenting information, and indicated that the assignment enhanced their learning. In a survey from 22 students in the CHM 110 (General Chemistry) course in Spring 2004, 73 \% replied either "strongly agreed" or "agreed" that working on the Periodic Table project (gathering and presenting information) enhanced their learning. Additionally, $68 \%$ answered as either "strongly agreed" or "agreed" that working on the Creative Project helped them connect their learning about chemistry to their personal interests.

Many students selected this project as a key piece in their course portfolio. In annotation, students described recognizing the responsibility for learning, utilizing previous learning from engineering courses, and enjoying different approach of learning. Following are a few excerpts from their annotations and comments, in their own words:

"Loved it! Really learned a lot about the element that way! It is my project."

"This allowed me to work other area of expertise into my life that I haven't been able to use for long time."

"I researched for reliable information to use in my projects ---"

"I learned a lot from this experience because I got to research an element to make my web page."

"I was happy with this because my classes were relating to each other and I was finally seeing a correlation."

"The poster project that I have done increased my interest about the subject."

"Quilting is my most favorite hobby and I thoroughly enjoyed taking a very fun, creative and original way for me to present my research on francium by making the francium quilt."

"It allowed me to use my computer skills from previous classes."

I use this project as an instructional demonstration tool when teaching relevant topics in my classroom. For example, I take the copper periodic table piece to the classroom when discussing oxidation and reduction and electron configuration. I show the francium quilt with its unit cell drawing to talk about crystal structures. I display the projects to promote science and diversity awareness during public outreach activities, such as College Open House and TWIST (Teen Women in Science and Technology) Career Day at Kansas State University at Salina. In 2004, I shared this project, in its preliminary

Proceedings of the 2005 American Society for Engineering Education Annual Conference \&Exposition Copyright (C) 2005, American Society for Engineering Education 
format with various student works, at the American Chemical Society National Meeting and the regional American Society for Engineering Education Midwest Section conference.

\section{Discussion}

Many students in engineering technology programs come to chemistry class with little personal interest and take it only because it is required in their curriculum. The goal of this assignment is to transfer the excitement students have in a personal "hobby" to learning about chemistry. This project was successful in motivating students to combine their personal interests studying chemistry and in incorporating kinesthetic learning styles. This non-traditional teaching strategy has also increased my enthusiasm to know my students on a personal level through observations of their unique talents and ways of connecting chemistry with engineering technology program courses.

Bibliography

1. Chickering, A. W., and Gamson, Z.F. (1987). Seven principles of good practice in undergraduate education AAHE Bulletin, 39(7) 3-7.

2. Bonwell, C and Fleming, N.D. How do I learn best? (learning styles survey) http://www.vark-learn.com/english/index.asp

3. Handley, M. K (1999). Portfolio assessment as a measure of student and program success. Proceedings of the 1999 ASEE Annual Conference. http://www.asee.org/acPapers/99conf414.PDF

4. Towns, M. H. (2001)

Kolb for chemists: Experiential learning theory Journal of chemical Education, 78(8) 1107

5. http://www.k-state.edu/catl/uge/

\section{JUNG OH}

Jung Oh is an Associate Professor at Kansas State University's College of Engineering Technology and Aviation in Salina. She earned her Ph.D. in Inorganic/Organometallic Chemistry from UCLA and was an ASEE postdoctoral fellow. She participated in the 2004 Wakonse Conference on College Teaching. Her interests in scholarship on teaching include online hybrid instruction and cross-curricular innovation.

Proceedings of the 2005 American Society for Engineering Education Annual Conference \&Exposition Copyright (C) 2005, American Society for Engineering Education 